\section{Chronic extraction of forest resources is threatening a unique wildlife habitat of the Upper Brahmaputra Valley, northeastern India}

\author{
Narayan Sharma ${ }^{1,2, *}$, Ankita Sharma ${ }^{1}$, \\ Bitupan Deka ${ }^{1}$ and Anindya Sinha ${ }^{1,2,3}$ \\ ${ }^{1}$ Department of Environmental Biology and Wildlife Sciences, \\ Cotton University, Panbazar, Guwahati 781 001, India \\ ${ }^{2}$ National Institute of Advanced Studies, \\ Indian Institute of Science Campus, Bengaluru 560 012, India \\ ${ }^{3}$ Indian Institute of Science Education and Research Kolkata, \\ Mohanpur 741 246, India
}

This study examines the extent and nature of harvest of non-timber forest products (NTFP) by local human communities residing adjacent to the Hollongapar Gibbon Sanctuary in the Upper Brahmaputra Valley of Assam, northeastern India. The harvest of NTFP was monitored at 15 entry points to the sanctuary over a period of 41 days. Dry timber was the most dominant form of NTFP collected and the most preferred firewood species was Vatica lanceaefolia, a critically endangered tree species. About $25 \%$ of the harvested NTFP were food plants for the six primate species of the sanctuary. Highlighting the threats posed by this chronic extraction of NTFP to the vegetation and unique primate assemblage of the sanctuary, we recommend measures to check the unsustainable extraction of natural resources from this shrinking, and now highly threatened, forest patch.

Keywords: Hollongapar Gibbon Sanctuary, non-timber forest products, primates, sustainability, Vatica lanceaefolia.

NON-TIMBER forest products (NTFP) collection supports about 60 million people globally and helps meet their demands for sustenance, fuelwood, fodder, house construction materials, and other cultural and traditional activities ${ }^{1}$. In India, NTFP absorb $55 \%$ of the total employment in the forestry sector and add to $50 \%$ of forest revenues and $70 \%$ of forest-based export income, thus providing household income for about one-third of the total population ${ }^{2}$. A large number of indigenous communities of northeast India depend heavily on forest resources and products for their livelihoods, but more extensively on NTFP, which play a significant role in their subsistence and food security ${ }^{3}$.

NTFP harvest is often considered sustainable as it provides resources and livelihoods to people living in the vicinity of forests, thus potentially subject to selfregulation and being less destructive to forests, compared to tree-felling for timber ${ }^{4,5}$. It is also often assumed that

\footnotetext{
*For correspondence. (e-mail: narayan.sharma@cottonuniversity.ac.in)
}

local communities have the knowledge to use and manage the forest sustainably, thus contributing towards community-based conservation. In many countries, therefore, governments and NGOs promote NTFP for improvement of rural economy, community development and forest conservation $^{6,7}$. Moreover, various international agencies have incorporated sustainability of NTFP into their research and development agenda ${ }^{3}$.

However, NTFP harvest has multiple ecological impacts ${ }^{8}$. Chronic leaf harvesting, for example, reduces reproductive success of tropical dry forest palms in Mexico ${ }^{9}$. In general, the impacts of NTFP harvest can range from the survival, growth or reproduction of the harvested individuals ${ }^{10}$, to demographic and genetic changes at the population level as well ${ }^{11}$. Although large forests can potentially buffer the impact of exploitation caused by NTFP collection, smaller habitat fragments are often prone to degradation, both qualitatively and quantitatively.

Here, we report a potentially unsustainable harvest of NTFP from the Hollongapar Gibbon Sanctuary in Jorhat district, Assam, northeastern India. Although the last remnant lowland rainforest patches of the Upper Brahmaputra Valley have been subjected to varying degrees of NTFP harvest by the local communities over decades, data on the extent and nature of such NTFP collection remain virtually non-existent. This study thus aimed to document the extent and pattern of NTFP harvesting in one such forest patch of the valley with its unique floral and faunal assemblages.

The sanctuary, with an area of 20.98 sq. km, is completely isolated and surrounded by tea plantations, agricultural fields and human settlements. The forest type is described as Assam Plains Alluvial Semi Evergreen Forests $\mathrm{I} / 2 / 2 \mathrm{~B} / \mathrm{CIn}$ with pockets of Wet Evergreen Forest ${ }^{12}$. The forest canopy is dominated by species such as Dipterocarpus ratusa, Artocarpus chama, Castonopsis sp., Mesua ferrea, Vatica lanceaefolia and Dillenia indica. The lower and ground canopy includes shrubs like Forrestia mollissima, bamboos such as Pseudostachyam polymorphum and Calamus sp., and various herbs. The sanctuary harbours six primate species, including the endangered western hoolock gibbon Hoolock hoolock and the rare stump-tailed macaque Macaca arctoides ${ }^{13}$, and is home to around 200 species of birds, including the endangered white-winged duck Asarcornis scutulata ${ }^{13}$. The local human communities comprise tea tribes (tea-garden workers belonging to the backward castes and tribes brought to Assam by British colonial planters in the 19th century), farmers, owners of small tea gardens and employees in the private and government sectors.

We identified 15 locations along the forest boundary frequently used by the local people to extract NTFP (Figure 1). At each sampling point, we monitored the entry and exit of people from early morning to late evening. Upon encountering a group of collectors, we recorded 


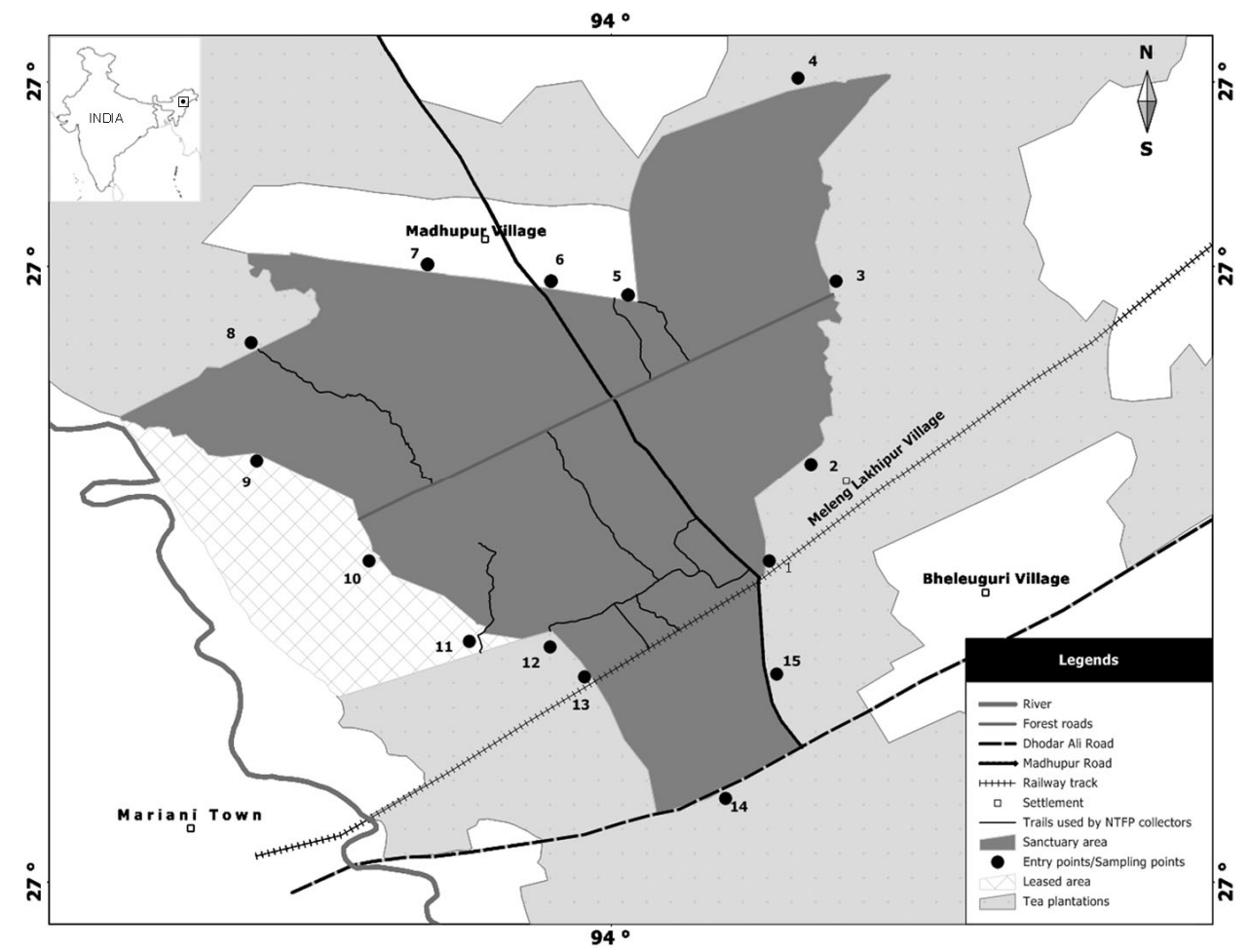

Figure 1. The Hollongapar Gibbon Sanctuary, Assam, India, showing the sampling locations.

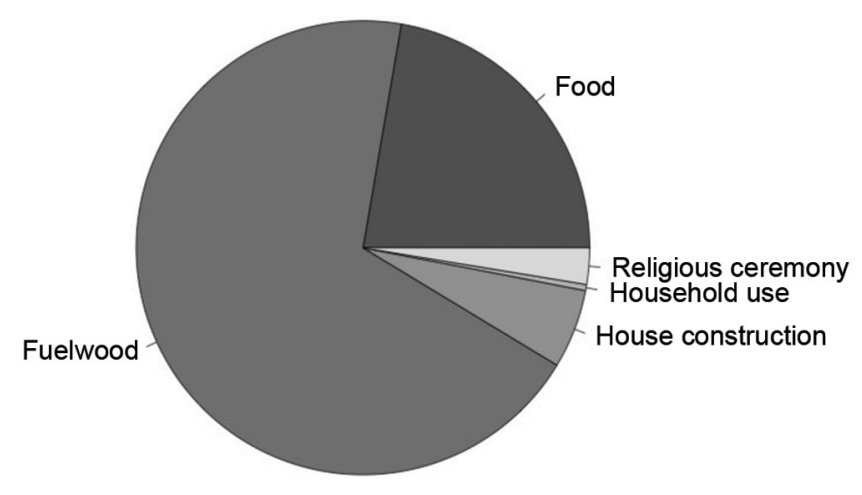

Figure 2. Utilization of NTFP extracted from the sanctuary.

their gender, group size, ethnic identity and age along with their time of entry and exit. We interviewed the collectors to determine the species harvested, plant parts collected and the purpose of such harvesting. All collected materials were identified up to the species level, whenever possible. Various details of each headload/cycle load were evaluated, including its weight $(n=407)$.

We observed NTFP collection at 15 different locations along the boundary of the sanctuary over a total of $281 \mathrm{~h}$ in 41 days, between January and May 2010. Although we collected data over only one season, we have predicted an annual estimate of the NTFP harvest. Each location was sampled thrice, except for four locations: 9 to 12 , sampled only twice. We encountered 113 groups of people consisting of 407 individuals, with a demographic composition of $71 \%$ belonging to the tea tribes, $20 \%$ to the Assamese and 9\% to the Nepali linguistic groups. About $72.5 \%$ of the collectors were male and approximately $80 \%$ belonged to the age group of $26-45$ years (median of 32).

We calculated about $63.11 \%$ of the collected NTFP to be in the form of dry branches, of which $76.17 \%$ was used as fuelwood (Figure 2). The mean headload/cycle load carried by females was $25.94 \mathrm{~kg}$ ( \pm SE of 2.59 , $n=112)$ and that by males $28.47 \mathrm{~kg}( \pm 2.30, n=295)$, with an average of $27.80 \mathrm{~kg}( \pm 2.21) \mathrm{kg}$. Although we were unable to identify all the harvested dry wood, Vatica lanceaefolia - a critically endangered dipterocarp tree species - accounted for $22.29 \%$ of the collection (Figure 3 ), while more than $25 \%$ of the species harvested were food plants of the different primate species that inhabit the sanctuary $^{14}$. A total biomass of $10,538.15 \mathrm{~kg}$ was extracted from the forest during the study period; these included dry timber, green wood, fish, herbs, shrubs, tubers, live trees and resins.

This diversity of forest biomass collection, which includes, in addition, fresh wood poles, fruits, medicinal plants or animal products, ensures the food and livelihood security of many of the local communities living in the forest or its fringe areas ${ }^{4}$. The tea tribes are mostly dependent on the forest for dry timber, used mainly for house construction and as fuelwood. Although most of the firewood collected was for subsistence, some of it 


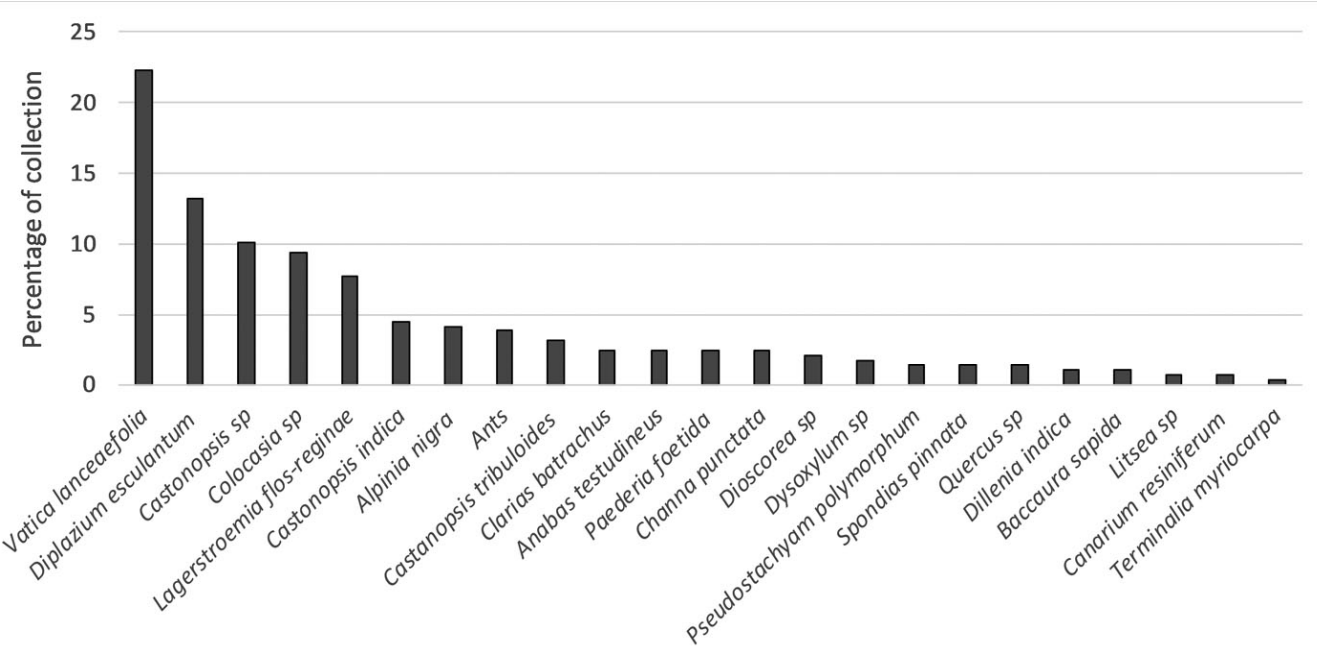

Species collected

Figure 3. Species collected and their percentage contribution to the total NTFP collection.

was used in charcoal production and supplied to roadside eateries along the neighbouring national highway or sold in the market in the nearby town of Mariani (N.S., pers. obs.).

There was a significant gender variation in NTFP collection amongst the different ethnic groups, with active female and male collectors from the tea tribes, but with the Assamese and Nepali linguistic communities completely lacking female or male collectors respectively. Conservation measures may, therefore, need to be designed more efficiently and address themselves to particular gender groups, if certain communities are found to be responsible for unsustainable harvest of NTFP, both spatially and temporally.

Intensive and uncontrolled harvest can reduce the abundance of certain plant species ${ }^{10}$. In this study, $V$. lanceaefolia was the most widely exploited taxon for NTFP collection and this could pose a significant threat to its populations in the area. The fuelwood collectors frequently cut medium to large saplings and live trees, and left the material to dry in the forest for a week, returning later to harvest them, at potentially unsustainable levels. Vatica is a critical mid-canopy element, providing structural connectivity for endangered arboreal mammals such as primates and squirrels (N.S., pers. obs.). Its continuous extraction may, therefore, affect its persistence in this dwindling forest patch, besides altering forest structure and composition, with far-reaching ecological consequences. Various earlier studies have, in fact, shown that NTFP over-collection can indeed negatively affect the forest biota ${ }^{15}$.

We observed about $3800 \mathrm{~kg}$ of biomass being extracted from the sanctuary on a daily basis, leading us to estimate an annual harvest of about $1,385,558 \mathrm{~kg}$ of biomass from the sanctuary, taking into account our 15 study locations but disregarding any spatial or temporal variation of such collection over the year. This, we believe, is an unsustainable level of NTFP collection for a small forest patch such as this and is likely to not only degrade the forest structure but also affect faunal groups, especially its unique assemblage of primate species. The collected species included several food plants of primates such as Artocarpus chama, Dillenia indica, Forrestia mollissima and Calamus sp. This could increase competition amongst the primate species and populations, hence directly affecting their survival and reproduction. Moreover, the loss of large trees like $V$. lanceaefolia, Lagerstroemia flos-reginae and Castonopsis sp. can lead to a serious degradation of valuable primate habitats, primarily through the opening up of forests and fragmenting them, and also by allowing the entry of humans into previously impenetrable habitats, leading to a rise in the often detrimental human-primate interactions. In Senegal, for example, it was found that chimpanzees were forced to compete with the local people for access to resources like honey, water or wild fruits in certain increasingly exploited forest patches ${ }^{16}$.

Poverty, lack of development as well as poor implementation of government schemes appeared to be some of the important factors responsible for such large-scale dependence of the local human communities on the sanctuary. The tea tribes are typically daily-wage workers and unable to afford LPG for cooking, resulting in their continued dependence on the forest. They were also able to earn some revenue by selling the collected NTFP in the nearby markets. Attention must, however, also be focused on the Assamese and Nepali linguistic communities, who contribute to NTFP harvesting in smaller amounts. Although LPG has been distributed among many of these communities in the area, its high price ensures that most 
households cannot afford it and hence, they continue to remain dependent on dry wood collected from the sanctuary.

In conclusion, we strongly recommend the plantation of fast-growing firewood species, such as Dalbergia sissoo, Acacia auriculiformis, Gmelina arborea and Ailanthus excelsa in the villages adjoining the sanctuary and along the boundary of the tea plantations to meet the fuelwood needs of the people. Additionally, the use of alternative fuel sources, such as LPG, should be encouraged under government schemes, such as the Pradhan Mantri Ujjwala Yojana. Previous attempts in this direction have, however, failed because of the significant cost involved in refilling gas cylinders. Finally, appropriate alternative livelihood options need to be urgently considered for those involved in the commercial harvest of NTFP. An example of such options includes the training and recruitment of members of the local communities as forest guides by government agencies and nongovernmental organizations, as the sanctuary attracts a significant number of wildlife tourists every year. These individuals can also regularly be employed to monitor the flora and fauna of the sanctuary, important indicators of the health of this unique, though increasingly threatened, lowland rainforest patch of northeastern India.

1. Shackleton, S., Paumgarten, F., Kassa, H., Husselman, M. and Zida, M., Opportunities for enhancing poor women's socioeconomic empowerment in the value chains of three African nontimber forest products (NTFPs). Int. For. Rev., 2010, 3, 151-163.

2. Pandey, A. K., Tripathi, Y. C. and Kumar, A., Non-timber forest product for sustainable livelihood: challenges and strategies. Res. J. For., 2016, 10, 1-7.

3. Dattagupta, S. and Gupta, A., Non-timber forest product (NTFP) in northeast India: an overview of availability, utilization, and conservation. In Bioprospecting of Indigenous Bioresources of North-East India (ed. Purkayastha, J.), Springer, Singapore, 2016, pp. 978-981.

4. RosTonen, M. A. F., The role of non-timber forest products in sustainable tropical management. Holz Roh. Werkst., 2000, 58, 196201.

5. Belcher, B. M. and Vantomme, P., What isn't an NTFP? Int. For. Rev., 2003, 5, 161-168.

6. Dangi, R. B., Impact of NTFP harvesting in forest conservation. Initiation, 2008, 2, 165-171.

7. Shmatkov, N. and Brigham, T., Non-timber forest products in community development lessons from the Russian Far East. For. Chron., 2003, 79, 113-118.

8. Ticktin, T. and Shackleton C., Harvesting non-timber forest products sustainably: opportunities and challenges. In Non-timber Forest Products in the Global Context (eds Shackleton, S., Shackleton, C. and Shanley, P.), Springer, Berlin, Heidelberg, 2011, pp. 149-169.

9. Ahossou, O. D., Fandohan, B., Stiers, I., Schmidt, M. and Assogbadjo, A. E., Extraction of timber and non-timber products from the swamp forest of Lokoli (Benin): use patterns, harvesting impacts and management options. Int. For. Rev., 2017, 19, 133-144.

10. Lopez-Toledo, L., Perez-Decelic, A., Macedo-Santana, F., Cuevas, E. and Endress, B. A., Chronic leaf harvesting reduces reproductive success of a tropical dry forest palm in northern Mexico. PLoS ONE, 2018, 13, e0205178.
11. Ticktin, T. and Nantel, P., Dynamics of harvested populations of the tropical understory herb Aechmea magdalenae in old-growth versus secondary forests. Biol. Conserv., 2004, 120, 461-470.

12. Champion, S. H. G. and Seth, S. K., A Revised Survey of the Forest Types of India, Manager of Publications, Government of India, 1968.

13. Sharma, N., Sengupta, S., Boruah, D., Saikia, L. and Saikia, G., White-winged duck Asacornis scutalata in Hollangapar Gibbon Sanctuary, Assam, India. Indian Birds, 2015, 10, 121-123.

14. Sharma, N., Primates on the edge: ecology and conservation of primate assemblages in the fragmented lowland rainforests of the Upper Brahmaputra Valley, Northeastern India. Doctoral thesis, National Institute of Advanced Studies, Bengaluru and Manipal Academy of Higher Education, Manipal, 2013.

15. Ticktin, T., The ecological implications of harvesting non-timber forest products. J. Appl. Ecol., 2004, 41, 11-21.

16. Carter, J., Ndiaye, S., Pruetz, J. and McGrew, W. C., Senegal status survey and conservation action plan: West African chimpanzees. In Status Survey and Conservation Action Plan: West African Chimpanzees (eds Kormos, R. et al.), IUCN, Gland, Switzerland and Cambridge, UK, 2003, pp. 31-40.

ACKNOWLEDGEMENTS. We thank late Noren Bhuyan and Dilip Baruah for help with data collection and the Rufford Foundation, London, UK, for a grant that enabled this study. We also thank the two anonymous reviewers for their critical comments that helped improve the manuscript.

Received 20 December 2019; revised accepted 9 July 2020

doi: $10.18520 / \mathrm{cs} / \mathrm{v} 119 / \mathrm{i} 6 / 1042-1045$

\section{Genetic homogeneity in brown planthopper, Nilaparvata lugens (Stål) as revealed from mitochondrial cytochrome oxidase I}

\section{N Srinivasa $^{1}$, Subhash Chander ${ }^{2, *}$, Twinkle ${ }^{2}$ and Rahul Kumar Chandel ${ }^{2}$}

${ }^{1}$ Department of Entomology and Agricultural Zoology, Banaras Hindu University, Varanasi 221005 , India

${ }^{2}$ Division of Entomology, ICAR-Indian Agricultural Research Institute, New Delhi 110 012, India

Brown planthopper, Nilaparvata lugens (Stål) is a seasonal migrant pest in North India. The present study analyses the genetic diversity of $N$. lugens by employing a partial fragment of the mitochondrial gene encoding cytochrome oxidase I (COI) using samples from 16 different localities of India. Total of 16 fulllength COI gene sequences generated from this study

*For correspondence. (e-mail: schanderthakur@gmail.com) 